特集 10

脺頭十二指腸切除例の治療成績とその問題点， とくに 乳頭部癌, 下部胆管癌, 膵頭部癌について

久留米大学第 2 外科

中山和道津 留昭 雄

\title{
SURGICAL RESULTS POSTOPERATIVE PROBLEM AFTER PANCREATICODUONDENECTOMY FOR THE CANCER LESION ESPECIALY IN THE PAPILLAVATER, CENTRAL OR DISTAL BILE DUCT, AND HEAD OF PANCREAS
}

Toshimichi NAKAYAMA and Akio TSURU

2nd Department of Surgery, Kurume University School of Medicice

膵頭十二指腸切除術 $(\mathrm{PD})$ 施行例, 205例中, 乳頭部癌76例, 中下部胆管癌55例, 膵頭部癌39例でこ の三者で170例, $82.9 \%$ を占めていた。 直接成績では 205 例中直死例は 9 例 $4.4 \% て ゙$, 乳頭部癌 3 例, 下 部胆管癌 3 例, 膵頭部癌 2 例, 胆慗癌 1 例でいずれも悪性疾患であった. 合併症は膵が正常に近い例, 払大した手術例にみられた。遠隔成績では 5 生率は乳頭部癌 $54.1 \%$, 中下部胆管癌 $24.4 \%$, 膵頭部癌 $19.8 \%$ ，乳頭部癌では十分なリンパ節郭清により著明な成績の向上をみた。下部胆管癌の再発因子 の検討から肝外胆管は全切除が必要である。長期生存例の術後の病態はほほ漓足すべき結果であり, PD-I, PD-II も良い消化管再建術式である.

索引用語：乳頭部癌, 中下部胆管癌, 膵頭部癌

1.はじめに

当科に和ける膵頭十二指腸切除術 (以下 $\mathrm{PD}$ ) 施行症 例のらち, PDの好適応例である乳頭部癌, 中下部胆管 癌および膵頭部癌の治療成績とその問題点について述 ベる.なお, 肝外胆道系の区分, リンパ節名, リンパ 節郭清の程度, 組織学的膵浸潤の程度などは胆道癌取

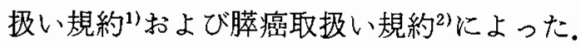

\section{2. 症例の概要}

1）施行症例と直接成績

$\mathrm{PD}$ 施行例205例の内訳は表 1 のごとくで悪性疾患 188例，良性疾患17例で, $91.7 \%$ 悪性疾患に行ってお りその中でも乳頭部癌76例, 中下部胆管癌55例, 膵 頭部癌39例之, 膵頭部領域癌で170例 $82.9 \%$ 占めてい た.

$\mathrm{PD}$ 施行例205例の直接成績は直死例 9 例, 直死率

*第33回日消外会総会シンポII ・脺頭十二指腸切除術

$<1989$ 年 5 月 25 日受理 $>$ 別刷請求先 : 中山 和道

干830 久留米市旭町 67 久留米大学医学部第 2 外科
表 1 膵頭十二指腸切除術症例

\begin{tabular}{|c|c|c|c|}
\hline & 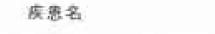 & 在毗 & 直死俉 \\
\hline \multirow{9}{*}{ 悪性疾㫣 } & 乳頭部舟 & 76 & 3 \\
\hline & 胆管癌 & 55 & 3 \\
\hline & 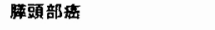 & 39 & 2 \\
\hline & 十二指軻悪性胜激 & 8 & \\
\hline & 霄痓 & 3 & \\
\hline & 䄽頭部カルチノイト & 3 & \\
\hline & 胆喜在 & 2 & 1 \\
\hline & 䐙カルチノイト & 1 & \\
\hline & 胼頭部領域毬 & 1 & \\
\hline \multirow{7}{*}{ 良性疾患 } & 提性粹炎 & 11 & \\
\hline & 乳頭部腺腄 & 2 & \\
\hline & 巨大十二指晹暴瘦 & 1 & \\
\hline & 䑏要胞 & 1 & \\
\hline & Solid and Cystic Tumor & & \\
\hline & of the Pancreas & 1 & \\
\hline & 良性胆管狭案 & 1 & \\
\hline it & & 205 & $9(4.42)$ \\
\hline
\end{tabular}

4.4\%であった.

2) 術後合併症 
表 2 PD 症例の術後合併症

\begin{tabular}{|c|c|c|c|}
\hline 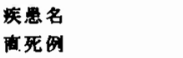 & 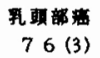 & $\begin{array}{c}\text { 中下部盟管濇 } \\
55 \text { (3) }\end{array}$ & $\begin{array}{r}\text { 笋期部慻 } \\
39(2)\end{array}$ \\
\hline \multicolumn{4}{|l|}{ 合不全 } \\
\hline 筆空膆昒合部 & $4(2)$ & $4(1)$ & $2(2)$ \\
\hline 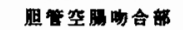 & & $3(1)$ & 1 \\
\hline 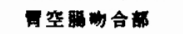 & 1 & & 2 \\
\hline \multicolumn{4}{|l|}{ 出眮 } \\
\hline 股䧑内出血 & $2(1)$ & $2(2)$ & \\
\hline 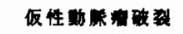 & $1(1)$ & & \\
\hline 消化管出血 & 3 & & 1 \\
\hline 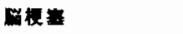 & & & $1(1)$ \\
\hline 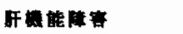 & $3(1)$ & 3 & 1 \\
\hline 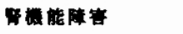 & & $1(1)$ & \\
\hline MOF & $1(1)$ & & \\
\hline 即合併主 & 1 & 1 & \\
\hline 目症ショック & & & $1(1)$ \\
\hline 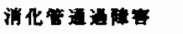 & 2 & 2 & 3 \\
\hline 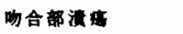 & 2 & 1 & \\
\hline 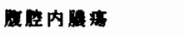 & 3 & 5 & 1 \\
\hline
\end{tabular}

乳頭部癌, 中下部胆管癌, 膵頭部癌の PD 施行例に術 後，表 2 のらな合併症が発生した。（）は直死につ ながったもので，因子としては複数のものが含まれて いる.

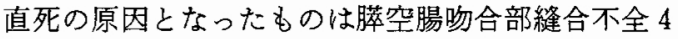
例，腹腔内出血 2 例，仮性肝動脈瘤破裂 1 例，高血圧 による脳出血 1 例であった.

\section{3. 乳頭部癌}

\section{1) 手術方法}

標準的術式として $\mathrm{R}_{2}$ のリンパ節郭清, 膵切離線は上 腸間膜静脈直上，胆管切離線は 3 管合流部より肝側の 総肝管の部位で行い, 後腹膜郭清は膵頭部の面する部 位のみ行なら程度の郭清を行ってきた。をた，術前の 画像診断 ${ }^{3)}$, 術中超音波検査により膵漫潤があるか, も しくは疑われる場合には膵切離線は大動脈左縁で行 い, 腹腔動脈の高さから下腸間膜動脈までの後腹膜郭 清を行っている4).

2）遠隔成績および予後を左右する因子

乳頭部癌の生存率は図 1 のごとくで, 5 年生存率(以 下 5 生率) は $54.1 \%$ で27例の 5 年生存例 (以下 5 生例) がでており良好な成績である。

昭和 48 年以前の腸間膜根部リンパ節(14)郭清は不確実 で，そのため比較的早期症例に沶いて明らかに(14)の残 存による癌死例を経験した。したがって昭和48年より (144の十分な郭清を含む $\mathrm{R}_{2}$ 郭清を行ってきた、次第に効 果が現われ，昭和56年には 5 生率は16\%であったが， 昭和63年にはリンパ節転移陽性例の 5 生率は図 2 のご
図 1 膵頭部領域癌の膵頭十二指腸切除術例の予後 (Kaplan-Meier 法)

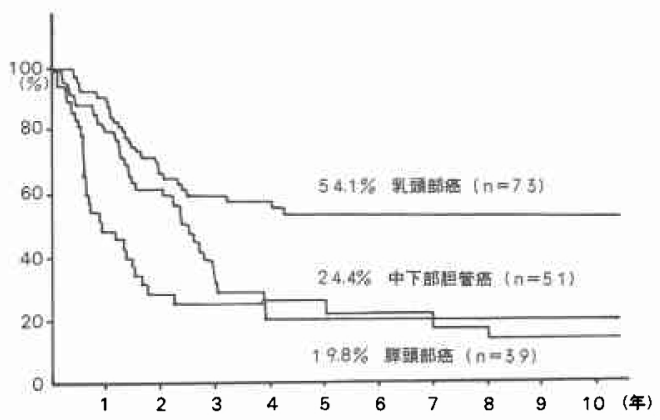

図 2 乳頭部癌の組織学的リンパ節転移と生存率 (Kaplan-Meier 法)

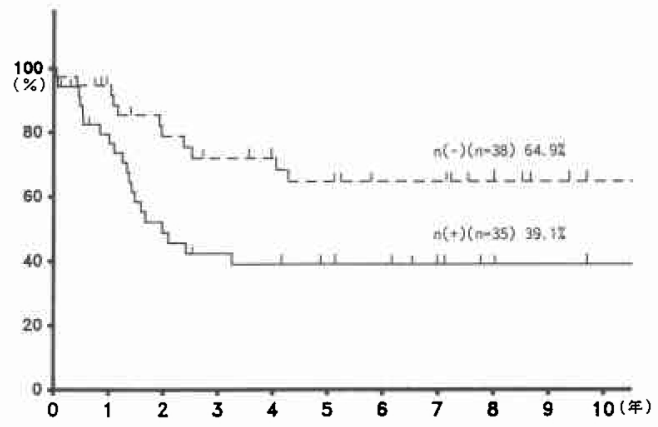

とく39\%と著明な向上を見た，とくに， $\mathrm{N}_{2}$ 症例で 6 例 の 5 生例がでている。

当科における乳頭部癌のリンパ節転移は $52 \%$ にみら れ，一番多いのは(13)a 31\%，つぎに(13)b 21\%である。 (14) abcdでみると各々 $5 \%$ ，7\%，5\%，2\%である が(14)全体としてみれば18\%で, (17)a 9\%, (17b $7 \%$ より 遙かに高い転移率であり, (14)の確実な郭清の重要性が らかがえる。

膵浸潤との関連では, panc 1 を panclaすなおち癌漫 潤が Oddi 筋および十二指腸壁を越えるが脺実質に達 していないものと, panclbすなわち癌浸潤が膵実質に 達するが $5 \mathrm{~mm}$ 末満のbのに分けて検討した. その 5 生 率は panc $078.5 \%$, panc1a $66.6 \%$, panc1b $30.9 \%$ で, panc $_{2}$ には前述のごとく, 膵頭部癌に準ずる術式を行 なっているがいまだ 5 生例をえていない.

\section{4. 中下部胆管癌}

1) 手術方法

下部胆管癌の標準的術式として $R_{3}$ (14)は第 3 群) の リンパ節郭清, 膵切離線は上腸間膜静脈值上, 胆管切 離線は右左肝管合流部直下の上部胆管癌で行ってき 
た. 胆管再発例が多くみられ，最近では肝内胆管第 1 分岐部直下まで切除している。また術前，術中の診断 で明らかな膵浸潤陽性例には乳頭部癌の膵浸潤例と同 様の術式を行っている4).

2）遠隔成績および予後を左右する因子

中下部胆管癌の生存率は図 1 のごとくで 5 生率は $24.4 \%$ で 8 例の 5 生例はでているものの不良である。

リンパ節転移陰性例の 5 生率は $38.4 \%$ であが転移 陽性例ではいまだ 5 生例をみていず最長で 3 年 2 か月 で再発死した症例であった。

膵浸潤の有無でみるに 5 生率は陽性例で $10.8 \%$ ，陰 性例で $62.5 \%$ で有意差（ $\mathrm{p}<0.001 ）$ が認められた.

乳頭部癌, 膵頭部癌では術後 3 年を過ぎると生存曲 線は 4 年, 5 年, 6 年と注涪平行な線となるが, 中下 部胆管癌では 3 年以後でも 4 年, 5 年, 6 年々漸次下 降線をたどっている，この原因を見るに術中迅速標本 で hw (一), 組織学的治瘜切除がなされ 3 年以上生存 した症例12例の中で 4 例に明らかな胆管断端再発例が みられ，大きな問題点がみられる。

\section{5. 腆頭部癌}

\section{1）手術方法}

Stage I, II 症例の標準的術式として $\mathrm{R}_{2}$ リンパ節郭 清, 膵切離線は大動脈左縁, 胆管切離線は上部胆管部, 腹腔動脈より下腸間膜動脈の間の後腹膜郭清を行って

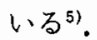

門脈合併切除は明らが門脈浸潤がみられる例のみ に行っており，血管合併症12例を含む，さらに広範囲 の後腹膜郭清をその他の症例に行ってきた。

2）遠隔成績および予後を左右する因子

膵頭部の生存率は図 1 のごとくで 5 生率は $19.8 \%$ で， 5 生例は 4 例のみで不良であった。

腫瑒径 $(\mathrm{T})$ と予後では明らかな相関はみられず， $\mathrm{T}_{1}$ で 5 生例はなく $\mathrm{T}_{2}$ で 2 例の 5 生例がある。

リンパ節転移陽性例の 5 生例は 1 例 $\left(\mathrm{n}_{1}\right)$ で他の 3 例 は陰性例であった。

膵周囲, 豩離面への癌浸潤 (ew) の有無で予後を比 較すると 2 年生存率では有意差を持って ew (一) 例の 予後は良好であり，5生例はいずれも ew（一)であっ た.

$\mathrm{pw}$ 因子では pw (+) 12例ではすべて 2 年以内に癌 死してる.

\section{6. 長期生存例の術後病態の検討}

当科に打ける消化管再建法はWhipple 法, Child 法, すなわち PD-Iおよび PD-IIで行ってきた。これら
図 3 体重と術後経過年数
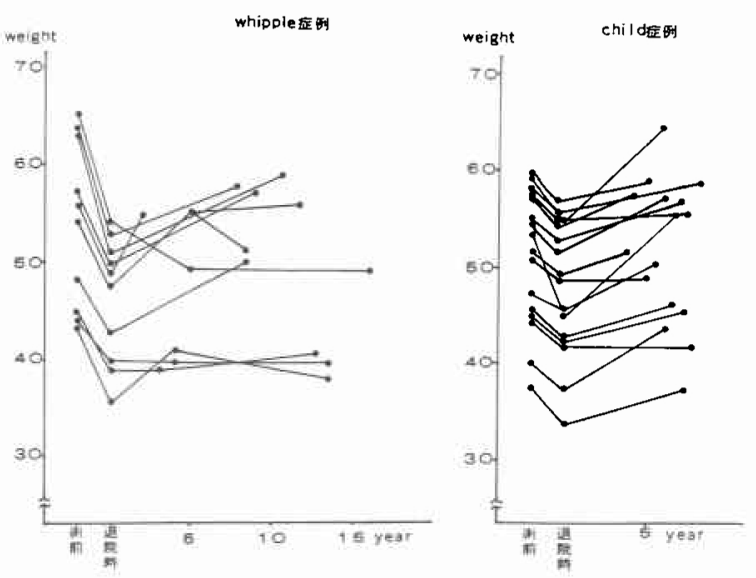

3 年以上長期生存例 (Whipple 法10例, Child 法16例) の術後病態について検討した。

1）体重の変動

消化呼吸状態の総合的指標である体重の変動を見る に図3のごとくWhipple 法, Child 法ともに退院時に 比べ体重の増加がみられ, 半数以上が術前に回復して いた。

2）その他

膵内分泌機能では残膵機能は膵切除量と残存膵の瀻 維化の程度に大きく依存されるが，一般に長期になる にしたがって漸次耐糖能は低下し，糖負荷による型分 類で境界型の約 $30 \%$ が糖尿病型に移行していた。しか し全例インスリンを必要とするほどではなかった。胆 管炎の発現状態についてみるに長期生存例では胆管炎 症状を示唆する所見 ( $38^{\circ} \mathrm{C}$ 以上の周期的発熱)を呈す る症例はみられなかった。

\section{7. 考 寨}

当科における $\mathrm{PD}$ 施行例205例のうち, 乳頭部癌76 例, 中下部胆管癌 55 例, 膵頭部癌39例でこの 3 者によ り 170例82.9\%を占め,これら膵頭部領域癌は PD の好 適应疾患といえる。その他の悪性疾患では十二指腸悪 性腫湯に 8 例行って括り，この8 例は遠隔成績は良好 で十二指腸悪性腫瘍もPDの良い適応である。良性疾 患では慢性膵炎が11例と多いが，その適応としては癌 の疑いでPDを行ったものであった。

直接成績では直死例は 9 例 $(4.4 \%)$ で，良性疾患に はなく, いずれも悪性疾患であり，乳頭部癌 3 例，下 部胆管癌 3 例, 膵頭部癌 2 例, 胆囊癌 1 例であった。 合併症は表 2 のごとく発生しており, 乳頭部癌, 胆管 
癌で脺が正常に近い例，および扗大した手術例に多く みられた。

膵空腸縫合不全の発生率は一連の縫合防止などにも とずく，手術手技，吻合法の改良により6) 9)，全体では $5 \%$ と少ないが, 発生例の $1 / 3$ 亿直死がみられ，常に注 意深く，愛護的な膵空腸吻合操作が必要である。

遠隔成績についてみるに乳頭部癌では 5 生率は $54.1 \%$ で常に $50 \%$ 以上の 5 生率で, 27 例の 5 年生存例 を党ており，ほぼ満足すべき成績と思われる。とくに 昭和48年より腸間膜根治リンパ節の十分な郭清を含む 確実な $\mathrm{R}_{2}$ の郭清を行うよらになり遠隔成績は著明に 向上し，現在 $39.1 \%$ ，とくに腸間膜根部リンパ節転 移陽性例に 6 例の 5 生例がでている.

しかしながら，脺浸潤陽性例では膵切離線を大動脈 左縁, $\mathrm{R}_{3}$ のリンパ節郭清, 後腹膜郭清を行っているが, Panclbでは30.9\%の5 生存率を得ているものの $\mathrm{Panc}_{2}$ ではいまだに 5 年生存例をえていない. 膵浸潤 陽性例ではリンパ節転移，脈管侵襲（ly.v）が著明で あり, 術中放射線療法, 十分な化学補助療法などに頼 らざるをえないことを痛感している。

中下部胆管癌では 8 例の 5 生例はでているるのの, 5 生率は $24.4 \%$ で, 乳頭部癌の半分であり, 不良であっ た。

再発死で明らかに胆管断端からの再発と思われる例 を多く経験し，最近では特に膵の上縁附近の癌では胆 管は肝外胆管をすべて切除すべく，第 1 分岐部まで切 除し，複数の胆管と吻合している。複数の肝内胆管と 空腸との吻合は，脺空腸吻合に先んじて，胆管空腸吻 合は最初に行った方が吻合操作が容易である。

リンパ節郭清は $\mathrm{R}_{3}$ の郭清を行っているにもかかわ らずリンパ節陽性例には 5 生例はみられず, リンパ節 転移陽性例は腫瘍す大さく進行した癌であるためとも 思われる。

当科においては胆管癌の遠隔成績向上に経皮経肝胆 道ドレナージの減黄期間中に PTBD 瘦孔を利用して の独自の温熱療法を行い，遠隔成績の向上に努めてい る.

膵頭部癌の 5 生率は $19.8 \%$ と不良であった。門脈合 併切除を含む広範囲リンパ節郭清, 後腹膜郭清などの 抎大した手術を行ってきたが，遠隔成績の向上にはつ ながらず 5 生例の 4 例はいずれも標準的手術に準じた 手術を行った症例であった。

最近では切除後術中放射線療法, 術後強力な化学補 助療法などを行っているが，いまだ遠隔成績の向上に
つながっていないのが現状である。

消化管再建法についてみるに PD-III 法は生理的な 再建法であると推浆されているがその長期的な術後病 態の報告は少ない, 当科では PD-III 方式の再建の経験 がなく比較されないが，当科の PD-I，PD-II 方式再建 の長期生存例では術後の体重の増加も汪とえどの例に みられ, 残膵機能子多少障害を伴らが保持されて抢り， 遠隔時の胆管炎症状はほとどみられず，大部分の例 が現職に復㷌しており，長期的にみても PD-I，PD-II 再建法は良い再建法である ${ }^{10) ~ 13)}$.

\section{まとめ}

1) $\mathrm{PD}$ 施行例, 205例中, 乳頭部癌76例, 中下部胆管 癌55例, 膵頭部癌 39 例之 3 者で 170 例, $82.9 \%$ を占めて いた。

2) $\mathrm{PD}$ 施行205例の直死例は 9 例， $4.4 \%$ で, 乳頭部 癌 3 例, 下部胆管癌 3 例, 膵頭部癌 2 例, 胆囊癌 1 例 といずれも悪性疾患で, 合併症は脺が正常に近い例, 拡大した手術例に多くみられた。

3）遠隔成績では 5 生率は乳頭部癌 $54.1 \%$, 中下部胆 管癌 $24.4 \%$, 膵頭部癌 $19.8 \%$ で後の 2 者は不良であっ た。

4）乳頭部癌では十分なリンパ節郭清により著明な 遠隔成績の向上を見た。中下部胆管癌の再発因子の㭘 討では肝外胆管の全切除が必要である。

5）長期生存例の術後の病態は性满足すべき結果 であり, PD-I, PD-II も良い消化管再建術式である。

本研究は厚生省対がん10か年総合戦略プロシェクト研究 助成費による。

\section{文献}

1）日本胆道外科研究会編：胆道癌取扱い規約（第 2 版). 金原出版, 1986

2）日本膵葴学会編：膵癌取扱い規約 (第 3 版)，金原 出版, 1986

3）中山和道, 吉田 正, 嬉野二郎ほか：乳頭部癌の診 断と治療一とくに進展度診断の可能性について。 外科診断 $31: 313-320,1987$

4）中山和道, 広瀬直樹, 桑原義明ほか：胆管癌におけ る進展度診断. 外科 Mook, 腹部外科に必要な新し い画像診断. 金原出版, 東京, 1988, p156-163

5）中山和道：膵癌に招ける外科治療と標準術式。医 のあゆみ $144: 504-507,1988$

6) 中山和道, 古賀道弘：胆道括よび膵頭部癌. 外科治 療 $23: 654-662,1970$

7）中山和道, 赤岩正夫, 篠崎哲宗ほ加：膵頭部十二指 腸切除. 外科診療 $14: 1300-1302,1972$

8）中山和道，小林重短：膵頭十二指腸切除に拈ける 縫合不全対策，日消外会誌 7：40-45，1974 
9）中山和道：膵頭十二指腸切除再建術, 膵空腸端吻 合. 外科 Mook, 消化管再建術. 金原出版, 東京, $1982, \mathrm{p} 412-420$

10）緒方蜂夫：脺頭十二指腸切除術後病態の検討. 日 消外会誌 $11: 954-964,1978$

11）内田立生：膵頭十二指腸切除後長期生存例におけ る再建術式の検討. 久留米医会誌 $49: 917-926$, 1986
12）中山和道, 内田立生, 友田信之ほか：当科に於ける 膵頭十二指腸切除後の再建法およびそれら長期生 存例の衍後病態の検討. 日消外会誌 $20: 909-$ 913, 1987

13）吉田 正, 中山和道, 嬉野二郎ほか：胆道癌長期生 存例の検討一乳頭部癌. 胆と脺 $8: 1205-1210$, 1987 